\title{
Country-Level Determinants of the Shadow Economy during 2005-2013: The Case of Greece
}

\author{
Rita Remeikiene \\ Kaunas University of Technology, Laisves str. 55, Kaunas, Lithuania \\ rita.remeikiene@ktu.It \\ Ligita Gaspareniene
}

Mykolas Romeris University, Ateities str. 20, Vilnius, Lithuania,

ligita.vasiliauskiene@ktu.lt

Jekaterina Kartasova

Mykolas Romeris University, Ateities str. 20, Vilnius, Lithuania,

jkartasova@gmail.com

Doi:10.5901/mjss.2014.v5n13p454

\begin{abstract}
In 2008, the average share of shadow economy in Europe was 19.4 percent, in 2012 - 19 percent, while in Greece these values of shadow economy were bigger: in $2008-24.3$ percent and in $2012-22.3$ percent of share of shadow economy. The scientists having researched shadow economy focused on the motives / reasons that prompt businessmen to operate underground. Shadow economy as a hidden factor is difficult to measure, making it necessary to use multiply observable indicators to approximate the extent of the shadow economy (Ruge, 2010). That is why such global organisations as the World Bank and others announce annual figures of shadow economy in most countries, including and evaluating their macroeconomic factors. The analysis of the scientific literature revealed that, in general sense, shadow economy emerges in such spheres as taxation, social security and labour aspects of undeclared work, so the aim of this article is not to measure the scope of shadow economy, but to identify what country-level determinants from the spheres mentioned above have the strongest impact on the scope of shadow economy in Greece during 2005-2013. The results of the research will enable to develop the recommended directions that could be followed seeking to reduce the scope of shadow economy in Greece.
\end{abstract}

Keywords: shadow economy, country-level determinants, Greece.

\section{Introduction}

The actuality of the topic. The size of shadow economies is a reflection of individual incentives to conceal their activities. Existing literature has identified a number of factors (e.g. the burden of taxation or regulation, the quality of government, legal enforcement, corruption, etc.) that create such incentives (Bose, et. al., 2012). Shadow economy very strongly correlates with economic cycles (Kearney, Schneider, 2013): the periods of economic downturn cause the increase of unemployment rate and the decrease of income. This raises fears and uncertainty about the future. That is why a part of individuals back out to the shadow, find extra jobs in which salaries are paid in „envelopes" and so forth. 2008 is the year considered to be the beginning of economic crisis. Comparing 2008 with 2009, it can be seen that the percentage of shadow economy from GDP increased by 0.5 per cent in all Europe while in Greece the share of shadow economy reached 24.5 per cent; in 2009 it increased by 0.5 per cent and made 25 per cent. In 2013, calculated share of shadow economy was 23.4 per cent, and this was the smallest rate of shadow economy in Greece during the analysed period.

Shadow economy in Greece was analysed by such scientists as Katsios (2006) and Manolas et al. (2013). According to Katsios (2006), underground economy is considered as one of the main negative effects deriving from serious structural problems of the Greek economy. The main determinants of the Greek shadow economy established by the author include tax and social security contribution burdens, intensity of regulations, public sector services and the corruption. These determinants were treated as the main referring to the qualitative analysis of the scientific literature. Using panel data for a group of 19 countries for the 2003 - 2008 period, Manolas et al. (2013) found that the quality of governance, the regulatory framework in the product, labour and credit markets and the tax burden both in the sense of the direct cost on entrepreneurial activity and the cost of compliance to the tax administration framework, are the most 
important factors affecting underground economy. The calculations revealed that there are strong links between hidden economy and corruption level in Greece in 2003 and 2008. The results of the research show that not all determinants were included in the calculations. That is why the analysis of the scientific literature has enabled the authors to fulfil this gap.

The scientific problem research level while analysing shadow economy:

- Determinants of the shadow economy within a standard Structural Equation Model (35 countries); Ruge, 2010; MIMIC model (24 countries); Herwartz et al. 2013; the relationship between unemployment rate and shadow economy in USA (Dell'Anno, Solomon, 2008); Schneider et. al., 2010; Acosta-Gonzalez, et. al. 2014.

- Policy approaches available for tackling undeclared work (Williams et. al. 2013; Williams, Nadin, 2012; Bourne, 2011).

- Research of the business sectors with the highest rate of informal economy (Williams, 2007); establishment of the motives and types of businessmen operating in the country (Williams, Nadin, 2012; Williams, Nadin, 2013; Williams, Martinez, 2014); Pathak, et. al., 2013; Ojo, et. al., 2013; Pathak, et. al., 2013.

- Benefits and drawbacks of informal economy (Hope Sr., 2014).

- Definitions and theoretical approaches of the informal economy (Godfrey, 2011).

- Nature of shadow economy in Baltic states (Williams, 2010).

The scientific problem has been formulated as follows: which country-level determinants are the main and have the most significant influence on the scope of shadow economy in Greece?

The purpose of the article is to establish and evaluate the main country-level determinants that have the most significant impact on the scope of shadow economy in Greece.

The purpose has been detailed into the following objectives: 1) to systematize country-level determinants and their impact on shadow economy; 2) to introduce the methodology of the research; 3) with reference to the results of mathematical calculations, to establish the main and the most influential country-level determinants of shadow economy in Greece during downturn.

The methods of the research include systematic and comparative analysis of the scientific literature, the analysis of the statistical data, correlation, multiple and simple regression analysis.

The first section of the article systematizes the country-level determinants that have the impact on the rate of shadow economy; the second section introduces the methodology of the empirical research including three calculation stages; the third section presents the interpretation of the results of the empirical research and, finally, the article has been finished with conclusions.

\section{Theoretical Consideration about the Impact of Country-Level Determinants to Shadow Economy}

According to Williams and Nadin (2012a), in the scientific literature, "45 different nouns and 10 adjectives have been used to denote the "informal economy" (p. 896). The most used synonyms of informal economy are "an official", "hidden". "black", "cash-in-hand", "shadow" economy, underground / undeclared work / economy / sector. Illegally accounted economy in its general sense apprears in the three following fields: the tax, social security and labour aspects of undeclared work (Williams, Nadin, $2012 \mathrm{a}, 2012$ b). The only distinctive feature between declared and undeclared work is that undeclared work is not declared to the public authorities for tax, social security and labour law purposes (Williams, Nadin, 2012b, p. 1759). To perform shadow economy research, Enste (2010) followed the definition defining that "the shadow economy includes unreported income resulting from the production of legal goods and services, either from monetary or barter transactions - and, hence, includes all economic activities that would generally be taxable were they reported to the (tax) authorities" (p. 560). According to Schneider et al. (2010), shadow economy includes all marketbased legal production of goods and services that are deliberately concealed from public authorities for any of the following reasons: 1) to avoid payment of income, value added or other taxes; 2) to avoid payment of social security contributions; 3) to avoid having to meet certain legal labour market standards, such as minimum wages, maximum working hours, safety standards, etc., and 4) to avoid complying with certain administrative procedures, such as completing statistical questionnaires or other administrative forms.

Systematization of the scientific literature on the country-level determinants that have the impact on the scope of shadow economy has enabled to establish the main ones which are usually applied while performing empirical research in this field (see Table 1). 
Table 1. Country-level determinants of shadow economy (source: compiled by the authors with reference to Herwartz et. al. 2013; Ruge, 2010; Enste, 2010; Schneider et. al. 2010)

\begin{tabular}{|c|c|c|}
\hline Author, year & Country-level determinants & Indicators \\
\hline \multirow{6}{*}{ Herwartz et. al. 2013} & Labour market conditions & Unemployment rate; the share of self-employed in the labour force; \\
\hline & Taxation & VAT rates; the level of tax rates \\
\hline & Rule of law index & The share of public employment in the labour force; the share of collected tax \\
\hline & GDP per capita & revenues in the tax base \\
\hline & The rate of labour force & Purchasing power standards (PPS) \\
\hline & participation & The level of employment \\
\hline \multirow{3}{*}{ Ruge, 2010} & Overall state & Wealth \&development level; administrative system; constitutional trust \&values \\
\hline & Tax system & Tax and social security payments; tax complexity \& surveillance; tax moral \\
\hline & Labour system & Labour market regulations; unemployment; participation rights; labour wages \\
\hline \multirow{4}{*}{ Enste, 2010} & Overall regulation & Tax burden (measured on the total tax and social security wedge, including \\
\hline & Labour & $\begin{array}{l}\text { employer contribution, less cash benefits of an average single earner; vAI); } \\
\text { Tax morale; unemployment rate }\end{array}$ \\
\hline & Product market regulation & GNP per capita \\
\hline & & IW regulation index \\
\hline \multirow[t]{3}{*}{ Schneider et. al. 2010} & Monetary indicators & The currency outside the banks and the currency outside the banks plus deposit \\
\hline & Labour market & Labour force participation rate; growth rate of the total labour force \\
\hline & $\begin{array}{l}\text { State of the official } \\
\text { economy }\end{array}$ & GDP per capita \\
\hline
\end{tabular}

Analysing country-level determinants that have the impact on the scope of shadow economy in both theoretical and practical level, the researchers face with problem since there is no clear-cut division between indicators and causal variables. Both causal variables and indicators might be included in the calculations of shadow economy scope and treated as synonymous factors. Further in the article, the results of previous scientific research on plausible impact of country-level determinants on shadow economy have been reviewed.

Labour market conditions. One of the indicators describing the conditions in the labour market is unemployment rate. With reference to Ojo et al. (2013), the informal economy moderates unemployment, although in numerous cases undeclared work does not provide any social guarantees and is low-paid. Unemployment is a cause for the increase in the supply of labour to the informal sector (Sookram et. al., 2009). The calculations aimed at identification of the impact of the determinants on shadow economy (Williams, 2007; Williams, Nadin, 2012b) also include self-employment and total labour force determinants. The majority of businessmen start-up their activities hiding a part of income and thus not paying taxes while the self-employed get wages in "envelopes" due to adverse circumstances, take up illegal works and so forth. All this increases the scope of shadow economy.

Taxation and Social Security Contribution Burdens. People engage in shadow economy activities for a variety of reasons - especially in response to government actions, most notably, taxation and regulation. High taxes as well as social security contribution burdens are the main motives for the emergence of shadow economy. The impact of these determinants was analysed by many scientists (Schneider et al., 2010; Ojo et. al., 2014; Sookram et. al., 2009). With reference to Schneider et al. (2010), the more significant is the difference between total cost of labour in the official economy and the after-tax earnings from work, the greater is the incentive to avoid this difference and to work in the shadow economy. According to Ojo et al. (2013), unofficial earnings such as tax evasion, avoidance of labour regulation and other government or institutional regulations, non-registration of the business and so on are all illegal activities which have a strong impact on personal motivation to remain in the shadow. Lisi, Pugno (2010) and Sookram et al. (2009) emphasize that lower taxation and lower start-up costs also reduce the hidden sector. The analysis of the previous research proposes that conclusion that higher taxation results in a higher undeclared share of income.

\section{Methodology}

With a view to establishing which country-level determinants have the most significant impact on shadow economy in Greece, several methods were selected: correlation analysis and multiple/simple regression. Seeking the accuracy of the calculation results, the period of 2005-2013 was selected. The course of the research included three stages. Firstly, correlation was calculated. Only the determinants with correlation coefficient equal or higher than 0.60 were selected for further stage of the research. Independent variable (y) - size of shadow economy -was expressed as percentage of GDP; independent variables $(\mathrm{x})$ and their correlation coefficients have been presented in Table 2. 
Table 2. The results of correlation analysis for Greece (source: compiled by the authors)

\begin{tabular}{|c|c|c|}
\hline Independent variable, mark. & Short description of the independent variable & Correlation \\
\hline Business freedom (x2) & $\begin{array}{l}\text { Business freedom is an overall indicator of the efficiency of government regulation of business. } \\
\text { The quantitative score is derived from an array of measurements of the difficulty of starting, } \\
\text { operating, and closing a business. The business freedom score for each country is a number } \\
\text { between } 0 \text { and } 100 \text {, with } 100 \text { equalling the freest business environment. (Source: Heritage } \\
\text { Foundation) }\end{array}$ & -0.462757 \\
\hline $\begin{array}{l}\text { Unemployment rate, percent } \\
\text { (x7) }\end{array}$ & $\begin{array}{l}\text { Total unemployment is described as a percentage of total labour force. Unemployment refers to } \\
\text { the share of the labour force that is without work but available for and seeking employment. } \\
\text { Definitions of labour force and unemployment differ by country. (Source: International Labour } \\
\text { Organization, Key Indicators of the Labour Market database) }\end{array}$ & -0.619904 \\
\hline $\begin{array}{l}\text { GDP per capita (purchasing } \\
\text { power parities EU-27) }(\times 6)\end{array}$ & $\begin{array}{l}\text { It corresponds to the GDP per capita based on purchasing power parity (PPP). GDP PPP is } \\
\text { gross domestic product converted to international dollars using purchasing power parity rates. } \\
\text { GDP at purchaser's prices is the sum of gross value added by all resident producers in the } \\
\text { economy plus any product taxes and minus any subsidies not included in the value of the } \\
\text { products. (Source: World bank) }\end{array}$ & -0.612733 \\
\hline $\begin{array}{l}\text { Labour force participation as } \\
\text { a percentage of the working } \\
\text { age population }(x 5)\end{array}$ & $\begin{array}{l}\text { It corresponds to the labour force participation rate, total (\% of total population). Labour force } \\
\text { participation rate is the proportion of the population that is economically active: all people who } \\
\text { supply labour for the production of goods and services during a specified period. (Source: } \\
\text { International Labour Organization) }\end{array}$ & 0.046949 \\
\hline Freedom from corruption $(x 4)$ & $\begin{array}{l}\text { Corruption erodes economic freedom by introducing insecurity and uncertainty into economic } \\
\text { relationships. The score for this component is derived primarily from Transparency } \\
\text { International's Corruption Perceptions Index (CPI). The CPI is based on a 10-point scale in } \\
\text { which a score of } 10 \text { indicates very little corruption and a score of } 0 \text { indicates a very corrupt } \\
\text { government.(Source: Heritage Foundation) }\end{array}$ & 0.557257 \\
\hline $\begin{array}{l}\text { Total labour force, thousands } \\
\text { (x9) }\end{array}$ & $\begin{array}{l}\text { The total labour force, or currently active population, comprises all persons who fulfil the } \\
\text { requirements for inclusion among the employed or the unemployed during a specified brief } \\
\text { reference period. (Source: ILO) }\end{array}$ & -0.632545 \\
\hline $\begin{array}{l}\text { General government final } \\
\text { consumption expenditure as } \\
\text { percentage of GDP at current } \\
\text { prices(x10) }\end{array}$ & $\begin{array}{l}\text { General government final consumption expenditure (formerly general government consumption) } \\
\text { includes all government current expenditures for purchases of goods and services (including } \\
\text { compensation of employees). It also includes most expenditure on national defence and } \\
\text { security, but excludes government military expenditures that are part of government capital } \\
\text { formation. } \\
\text { (Source: United Nations Statistical Database) }\end{array}$ & -0.041971 \\
\hline $\begin{array}{l}\text { Exports of goods and } \\
\text { services (\% of GDP) (x13) }\end{array}$ & $\begin{array}{l}\text { Exports of goods and services represent the value of all goods and other market services } \\
\text { provided to the rest of the world. } \\
\text { (Source: World bank) }\end{array}$ & -0.320715 \\
\hline $\begin{array}{l}\text { Imports of goods and } \\
\text { services (\% of GDP) (x14) }\end{array}$ & $\begin{array}{l}\text { Imports of goods and services represent the value of all goods and other market services } \\
\text { received from the rest of the world. } \\
\text { (Source: World bank) }\end{array}$ & -0.154788 \\
\hline $\begin{array}{l}\text { Domestic credit to private, \% } \\
\text { of GDP sector (x18) }\end{array}$ & $\begin{array}{l}\text { Domestic credit to private sector refers to financial resources provided to the private sector by } \\
\text { financial corporations, such as through loans, purchases of no equity securities, and trade } \\
\text { credits and other accounts receivable that establish a claim for repayment. } \\
\text { (Source: International Monetary Fund, International Financial Statistics and data files, and } \\
\text { World Bank and OECD GDP estimates) }\end{array}$ & -0.652392 \\
\hline $\begin{array}{l}\text { Final consumption } \\
\text { expenditure }(\% \text { of GDP) } \\
\text { (x11) }\end{array}$ & $\begin{array}{l}\text { Final consumption expenditure (formerly total consumption) is the sum of household final } \\
\text { consumption expenditure (private consumption) and general government final consumption } \\
\text { expenditure (general government consumption). } \\
\text { (Source: World Bank national accounts data, and OECD National Accounts data files) }\end{array}$ & -0.558167 \\
\hline $\begin{array}{l}\text { Total tax rate (\% of } \\
\text { commercial profit) } \\
\text { (x19) }\end{array}$ & $\begin{array}{l}\text { Total tax rate measures the amount of taxes and mandatory contributions payable by } \\
\text { businesses after accounting for allowable deductions and exemptions as a share of commercial } \\
\text { profits. Taxes withheld (such as personal income tax) or collected and remitted to tax authorities } \\
\text { (such as value added taxes, sales taxes or goods and service taxes) are excluded. Source: } \\
\text { World Bank, Doing Business project (http://www.doingbusiness.org/). }\end{array}$ & 0.951848 \\
\hline $\begin{array}{l}\text { Tax payment (number) } \\
\text { (x20) }\end{array}$ & $\begin{array}{l}\text { Tax payments by businesses are the total number of taxes paid by businesses, including } \\
\text { electronic filing. The tax is counted as paid once a year even if payments are more frequent. } \\
\text { Source: World Bank, Doing Business project (http://www.doingbusiness.org/). }\end{array}$ & 0.753257 \\
\hline
\end{tabular}

In the second stage, multiple regression has been calculated only for the determinants with value $r$ higher than 0.6 : - tax payment (x 20); 
- tax rate (x 19);

- domestic credit to private (x 18);

- total labour force (x 9);

- GDP per capita (x 6);

- unemployment rate $(x 7)$.

In the third stage of the empirical research, simple regression has been applied to estimate the scope of shadow economy and tax rate during the period of 2005-2013.

\section{Empirical Results of the Research}

As it can be seen from Table 3, R-squared for all multiple regression variables is equal to 0.97 . It means that the model by 97 per cent explains variability of the independent variables response data around the shadow economy mean, however, value $p$ is statistically important only for total tax rate $(X 19)$. Both total value $p(0.08)$ and values for other variables are statistically unimportant. Due to this reason, simple regression for variable X 19 was applied (see Table 4).

Table 3. The results of multiple regression for the shadow economy and country-level determinants (source: compiled by the authors)

\begin{tabular}{lcccc}
\hline \hline Variable & Coefficient & Std. Error & t-Statistic & Prob. \\
\hline \hline C & -82.33611 & 45.54482 & -1.807804 & 0.2124 \\
Domestic credit to private (X18) & -0.015746 & 0.020688 & -0.761090 & 0.5261 \\
Tax rate (X19) & 0.539931 & 0.116193 & 4.646862 & 0.0433 \\
Tax payment (X20) & -0.014629 & 0.064380 & -0.227231 & 0.8414 \\
Total labour force (X9) & 0.020703 & 0.010467 & 1.977841 & 0.1866 \\
Unemployment rate (X7) & 0.033016 & 0.038251 & 0.863122 & 0.4790 \\
GDP per capita (X6) & -21.39770 & 16.80797 & -1.273069 & 0.3310 \\
\hline R-squared & 0.971500 & Mean dependent var & 25.05556 \\
Adjusted R-squared & 0.886000 & S.D. dependent var & 1.239063 \\
S.E. of regression & 0.418356 & Akaike info criterion & 1.146511 \\
Sum squared resid & 0.350044 & Schwarz criterion & 1.299908 \\
Log likelihood & 1.840701 & Hannan-Quinn criter. & 0.815481 \\
F-statistic & 11.36256 & Durbin-Watson stat & 2.748455 \\
Prob(F-statistic) & 0.083086 & & & \\
\hline \hline
\end{tabular}

The results of simple regression showed that R-squared is $\mathbf{0 . 9 0}$, value $\mathrm{p}$ is statistically important and it is lower than 0.05 . Schwarz criterion value in Table 4 is lower than that in Table 3. Thus, final conclusions of the empirical research have been based on the results of simple regression. Graphical interpretation of the results has been presented in Figure 1.

Error column reveals that during the period of 2008 - 2010, actual shadow was higher than it had been fitted which could have been caused by the financial downturn taking place at the end of 2007.

Table 4. The results of simple regression for shadow economy and tax rate (source: compiled by the authors)

\begin{tabular}{|c|c|c|c|c|}
\hline Variable & Coefficient & Std. Error & t-Statistic & Prob. \\
\hline $\mathrm{C}$ & 6.968509 & 2.205966 & 3.158938 & 0.0160 \\
\hline Tax rate $(\mathrm{X} 19)$ & 0.381673 & 0.046463 & 8.214630 & 0.0001 \\
\hline R-squared & 0.906015 & Mean dependent var & & 25.05556 \\
\hline Adjusted R-squared & 0.892589 & S.D. dependent var & & 1.239063 \\
\hline S.E. of regression & 0.406086 & Akaike info criterion & & 1.228627 \\
\hline Sum squared resid & 1.154342 & Schwarz criterion & & 1.272455 \\
\hline Log likelihood & -3.528823 & Hannan-Quinn criter. & & 1.134047 \\
\hline F-statistic & 67.48015 & Durbin-Watson stat & & 2.099223 \\
\hline Prob(F-statistic) & 0.000077 & & & \\
\hline
\end{tabular}




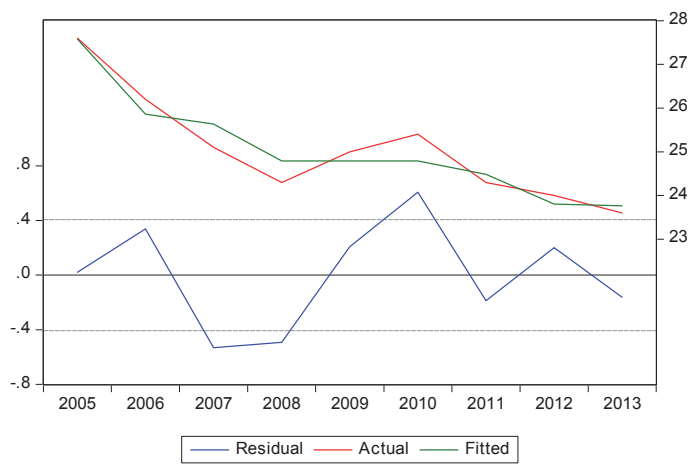

Fig. 1. Interdependence between the shadow economy and tax rate

The results of the empirical research have revealed that in order to reduce or regulate the scope of shadow economy, tax rate could have been used as the most influential determinant during he period of $2005-2013$. The total impact of other determinants made only 7 per cent since omission of them from the regression caused only 7 per cent variation loss. Thus, tax payment, domestic credit to private, total labour force, GDP per capita and unemployment rate have insignificant impact on the scope of shadow economy. The analysis of the impact of country-level determinants on the scope of shadow economy during the downturn in Greece has not been carried out due to too short data series. Although statistical data on shadow economy shows that during the downturn the shadow was only a few per cent lower than that during the pre-crisis period, this result could have been caused by the increased unemployment: in 2008, unemployment rate in Greece made 7.7 per cent while in 2013 it rose up to 27.3 per cent.

\section{Conclusions}

Country-level determinants that influence the scope of shadow economy in Greece are considered to be the most influential. Although the group of country-level determinants includes up to 15 factors, only a few of them - unemployment rate, GDP per capita, total labour force, domestic credit to private, tax rate and tax payment - are statistically significant and have the impact on shadow economy. Calculations confirmed the results of the theoretical research by showing that tax rate $\left(R^{2}=0.9\right)$ is the determinant having the most significant impact on shadow economy emergence and development. The impact of other determinants mentioned above is considerably weaker since omission of them from the regression caused only 7 per cent variation loss. The results of the research could be considered by the government of the country taking measures to reduce the scope of shadow economy. The authors of the article recommend carrying out a detailed analysis of the components of current tax structure in business and other spheres. This could contribute to introduction of the taxes which would not appear to be the fundamental motive to act in a shadow.

\section{References}

Acosta-Gonzalez, E., Fernandez-Rodriguez, F. \& Sosvilla-Rivero, S. (2014). An empirical examination of the determinants of the shadow economy, Applied Economics Letters, 21:5, 304-307, DOI:10.1080/13504851.2013.856993

Bose, N., Capasso, S., Wurm, M. A. (2012). The impact of banking development of the sixe of shadow economy. Journal of Economic Studies, Vol. 39, No. 6, pp. 620-638.

Bourne, M. (2011). Controlling the Shadow Trade. Contemporary Security Policy, 32:1, 215-240, DOI: 10.1080/13523260.2011.556863

Dell'Anno, R. \& Solomon, O. H. (2008). Shadow economy and unemployment rate in USA: is there a structural relationship? An empirical analysis. Applied Economics, 40:19, 2537-2555, DOI: 10.1080/00036840600970195

Enste, D. H. (2010). Shadow Economy - The Impact of Regulation in OECD countries. International Economic Journal, 24:4, 555-571, DOI: 10.1080/10168737.2010.525996

Godfrey, P. C. (2011). Toward a Theory of the Informal Economy. The Academy of Management Annals, 5:1, 231-277, DOI:10.1080/19416520.2011.585818.

Herwartz, H., Tafenau, E., Schneider, F. (2013). One share fits all? Regional variations in the extent of the shadow economy in Europe. Regional Studies, DOI: 10.1080/00343404.2013.848034

Hope, Sr., K. R. (2014). Informal economic activity in Kenya: benefits and drawbacks. African Geographical Review, 33:1, 67-80, DOI: $10.1080 / 19376812.2013 .838687$ 
International Labour Organization. ILOSTAT Database. [Online] Available: http://www.ilo.org/ilostat/faces/home/statisticaldata;jsessionid =99v6TSgGyqnOlkvGT7fswGyJWs1v33C5xrnZLqhJW0RMwNsJFBLV!1832651265?_afrLoop=2842986560448728\#\%40\%3F_afr Loop\%3D2842986560448728\%26_adf.ctrl-state\%3D1487husasx_4

International Monetary Fund. Domestic credit to private sector (\% of GDP). [Online]. Available: http://data.worldbank.org/indicator IFS.AST.PRVT.GD.ZS

Katsios, S. (2006). The shadow economy and corruption in Greece. South-Eastern Europe Journal of Economics 1, 61-80.

Kearney, A. T., Schneider, F. (2010). The shadow economy in Europe, 2013. [Online] Available: http://www.atkearney.com/documents /10192/1743816/The+Shadow+Economy+in+Europe+2013.pdf/42062924-fac2-4c2c-ad8b-0c02e117e428

Lisi, G. \& Pugno, M. (2010). Entrepreneurship and the Hidden Economy: An Extended Matching Model. International Economic Journal, 24:4, 587-605, DOI:10.1080/10168737.2010.526000.

Manolas, G., Rontos, K., Sfakianakis, G., Vavouras, I. (2013). The determinants of the shadow economy: the case of Greece. International Journal of Criminology and Sociological Theory, Vol. 6, No. 1, 1036-1047.

Ojo, S., Nwankwo, S. \& Gbadamosi, A. (2013). Ethnic entrepreneurship: the myths of informal and illegal enterprises in the UK. Entrepreneurship \& Regional Development: An International Journal, 25:7-8, 587-611, DOI:10.1080/08985626.2013.814717.

Pathak, S., Laplume, A. O. \& Xavier-Oliveira, E. (2013). A Multilevel Empirical Study of Ethnic Diversity and Shadow Economy as Moderators of Opportunity Recognition and Entrepreneurial Entry in Transition Economies. Journal of Balkan and Near Eastern Studies, 15:3, 240-259, DOI: 10.1080/19448953.2013.789305.

PWT 7.1 (189 countries and territories, 1950-2010, 2005 as reference year, released on: Nov 30, 2012). [Online]. Available: https://pwt.sas.upenn.edu/php_site/pwt71/pwt71_form.php

Ruge, M. (2010). Determinants and Size of the Shadow Economy - A Structural Equation Model. International Economic Journal, 24:4, 511-523, DOI:10.1080/10168737.2010.525988

Schneider, F., Buehn, A. \& Montenegro, C. E. (2010). New Estimates for the Shadow Economies all over the World. International Economic Journal, 24:4, 443-461, DOI: 10.1080/10168737.2010.525974

Schneider, F., Buehn, A., Montenegro, C. E. (2010). Shadow economies all over the world. New estimates for 162 countries from 1999 to 2007. Policy Research Working Paper 5356. [Online] Available: http://www-wds.worldbank.org/external/default IWDSContentServer/IW3P/IB/2010/10/14/000158349_20101014160704/Rendered/PDF/WPS5356.pdf

Sookram, S., Watson, P. K. \& Schneider, F. (2009). Characteristics of households in the informal sector of an emerging economy. Applied Economics, 41:27, 3545-3559, DOI: 10.1080/00036840701493733.

World Bank. Government final consumption expenditure (\% of GDP). [Online]. Available: http://data.worldbank.org/indicator INE.CON.GOVT.ZS

Williams, C. C., Nadin, S. (2012a.). Tackling the hidden enterprise culture: Government policies to support the formalization of informal entrepreneurship. Entrepreneurship \& Regional Development: An International Journal, 24: 9-10, 895-915, DOI: 10.1080/08985626.2012.742325

Williams, C. C., Nadin, S. (2012b.) Joining up the fight against undeclared work in Europe. Management Decision, Vol. 50, No. 10, 17581771.

Williams, C. C., Nadin, S. (2013). Harnessing the hidden enterprise culture. Supporting the formalization of off-the-books business startups. Journal of Small Business and Enterprise Development, Vol. 20, No. 2, pp. 434-447.

Williams, C., Martinez, A. (2014). Is the informal economy an incubator for new enterprise creation? A gender perspective. International Journal of Entrepreneurial Behaviour \& Research, Vol. 20, No. 1, pp. 4-19.

Williams, C., Windebank J., Baric, M., Nadin, S. (2013). Public policy innovations: the case of undeclared work. Management Decision, Vol. 51, no. 6, pp. $1161-1175$.

Williams, C. (2007). Small business and the informal economy: the evidence from the UK. International Journal of Entrepreneurial Behavior \& Research, Vol. 13, No. 6, pp. 349-366.

Williams, C. C. (2010). Out of the Shadows: Explaining the Undeclared Economy in Baltic Countries. Journal of Baltic Studies, 41:1, 322, DOI:10.1080/01629770903525282. http://www.heritage.org/index/explore?view=by-region-country-year

World Bank. Doing business. [Online]. Available: http://www.doingbusiness.org/ 